\title{
ACCENT AND ABLAUT IN THE VEDIC VERB
}

\author{
Frederik Kortlandt
}

Most scholars nowadays reconstruct a static root present with an alternation between lengthened grade in the active singular and full grade in the active plural and in the middle. I am unhappy about this traditional methodology of loosely postulating long vowels for the proto-language. What we need is a powerful theory which explains why clear instances of original lengthened grade are so very few and restrains our reconstructions accordingly. Such a theory has been available for over a hundred years now: it was put forward by Wackernagel in his Old Indic grammar (1896: 66-68). The crucial element of his theory which is relevant in the present context is that he assumed lengthening in monosyllabic word forms, such as the $2^{\text {nd }}$ and $3^{\text {rd }}$ sg. active forms of the sigmatic aorist injunctive. Since the sigmatic aorist is the prototypical static paradigm in the verbal inflection, it offers the possibility of testing the relative merits of the two theories, Wackernagel's lengthening in monosyllabic word forms versus a static paradigm with lengthened grade in the singular and full grade in the plural. As I have pointed out elsewhere (1987), the evidence substantiates Wackernagel's view and forces us to reject the alternative because we find full, not lengthened grade in the $1^{\text {st }} \mathrm{sg}$. form, e.g. Vedic jeșam 'conquer', stoșam 'praise'. The only $1^{\text {st }} \mathrm{sg}$. active form with lengthened grade in the sigmatic aorist injunctive is rāvisam of the root $r u$ - 'hurt', which is clearly analogical. It is therefore reasonable to assume that originally the static present also had lengthened grade in the $2^{\text {nd }}$ and $3^{\text {rd }} \mathrm{sg}$. active forms of the injunctive and full grade elsewhere.

Following Hoffmann, Narten interprets jeșam and $1^{\text {st }}$ pl. RV. jeșma as precative forms (1964: 120). The reason for this interpretation is evidently the absence of lengthened grade (cf. Hoffmann 1967a: 254). The functional evidence for the interpretation as precative (Hoffmann 1967b: 32f.) or subjunctive (Insler 1975: $15^{26}$ ) is very weak, while the formal objections against it are prohibitive. It is therefore preferable to retain the traditional view that these forms are what they look like: full grade injunctive forms, which were interchangeable with the corresponding subjunctive in certain contexts and which could be interpreted as precative when the latter category became common.

Narten assumes that the injunctive forms yosam and stoșam took their vocalism from the subjunctive (1964: 213, 277). The model for this analogic development is lacking, however, because the subjunctive ending was $-\bar{a} n i$, not $-a m$. Hoffmann attributes the alleged substitution of the injunctive ending $-a m$ for the earlier subjunctive ending $-\bar{a}$ to the influence of the $2^{\text {nd }} \mathrm{sg}$. imperative: "Das Bestreben, den Konjunktivausgang $-\bar{a}$ von dem durch Auslautsdehnung gleichlautend gewordenen Imperativausgang zu sondern, hat das Ausweichen zu -am, wodurch die 1. Person deutlich gekennzeichnet wurde, gefördert" (1967a: 248). I find such influence highly improbable. The use of the $1^{\text {st }} \mathrm{sg}$. injunctive for the subjunctive must be explained from the meaning of the forms. Note that standard British English offers an exact parallel in the use of 'I shall' where other persons 'will'. During my stay in Dublin, Dr. Patrick Sims-Williams told me that when an Irish friend asked him in front of an open door: "Will I go first?", the only reasonable answer to him would be: "I don't know". Compare in this connection RV.VII 86.2 kadá 
nv àntár várune bhuvāni ... kadấ mṛ̣ikám sumánā abhí khyam 'When will I be inside Varuna? When shall I, cheerful, perceive his mercy?'. Also X 27.1 ásat sú me jaritah sábhivegó, yát sunvaté yájam ānāya síkș̣am 'That will be my excitement, singer, that I shall be helpful to the pressing sacrificer'. In X 28.5 kathấ ta etád ahám á ciketam 'How shall I understand this (word) of yours?', the substitution of the subjunctive for the injunctive would yield a quite different shade of meaning: it would shift the responsibility from the singer to Indra. Similarly VIII 74.15 dediśam 'I shall point out' must be identified as an injunctive (cf. Hoffmann 1967a: $253^{281}$ ), not a subjunctive (thus Schaefer 1994: 42f. "will ich [...] hinweisen"), and the same holds for yosam and stoșam. The injunctive presents the event as a fact without specifying its time frame. As a result, the listener has to supply a time frame in which the event is part of reality, and is driven by the context to choose the most obvious possibility. The subjunctive, however, presents the will to achieve a situation as part of reality, and thereby suggests that its accomplishment may be beyond the subject's control. The "Spezialfall" of the "Nebeneinander von Injunktiv und Konjunktiv in der 1. Person Singularis" (Hoffmann 1967a: 247) is a result of the fact that the first person can take full responsibility for his own actions, cf. also II 18.3 hárī nú kam rátha índrasya yojam āyái sūkténa vácasā návena "die Falben schirre ich nun an Indras Wagen ['now indeed shall I harness the steeds to Indra's chariot'] mit wohlgesprochener neuer Rede, auf daß er komme" beside I 82.1-5 yójā $n v$ indra te hárī "ich will dir nun deine Falben anschirren, Indra" followed by 82.6 yunájmi 'I harness' (Hoffmann 1967a: 253).

If Wackernagel's theory is correct, as I think it is, we also expect lengthened grade in the $2^{\text {nd }}$ and $3^{\text {rd }}$ sg. active forms of the root aorist injunctive. Perhaps the clearest piece of evidence for this original distribution is the long vowel in $3^{\text {rd }} \mathrm{sg} . * g^{w} \bar{e} m t$ 'came', Latin vēnit, Gothic qēm-, Toch. B śem, which can hardly be explained otherwise. Another instance is Greek $\sigma \beta \eta-<{ }^{*} s g^{w} \overline{e s t}$ '(the fire) went out' (cf. Ruijgh 1998: 226). A third example may be Old Irish ro-mídair 'he judged' < *mēd- of midithir 'judges' < *med-, Gothic $m \bar{e} t$ - 'measured', Greek $\mu \eta \delta$ - 'be disposed, inclined' beside $\mu \varepsilon \delta$ - 'be observant, attentive'. This raises the question of why in Indo-Iranian the long vowel was generalized in the sigmatic aorist indicative, which had fixed stress, and eliminated in the root aorist, which had mobile stress. The reason must be sought in the difference between static and dynamic paradigms. The problem will be taken up below.

We first have to establish the nature of the static present, which is not a frequent type of inflection. I subscribe to Dr. Alexander Lubotsky's unpublished theory that it must be derived from a reduplicated formation (cf. already Rix apud Harðarson 1993: 29 ${ }^{12}$ ). A clear instance is Vedic $3^{\text {rd }}$ sg. tâsțti, $3^{\text {rd }}$ pl. tákṣati 'fashion', which cannot be separated from Greek $\tau \varepsilon ́ \kappa \tau \omega v$ 'carpenter' $<*$ tetk-. Another example is Vedic $3^{\text {rd }} \mathrm{sg}$. dấṣti 'makes offering' beside dákșate 'is able' <*dedk- (cf. Lubotsky 1994: 204). These verbs may have provided a model for $k \bar{a} s$ - 'appear' beside cáste 'sees' $<* k^{w} e t s^{\prime}-<* k^{w} e k^{w} k$-, then

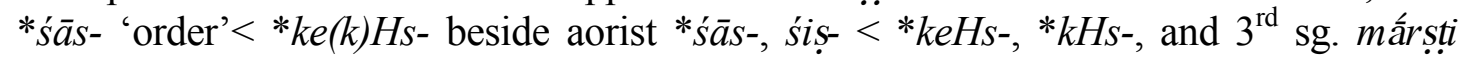
'wipes' <*me $(m) r g-$, stáuti 'praises' $<*^{*} s t e(s t) u$-, with lengthening of the vowel replacing the lost consonants. The original formation can be identified with Greek $\tau$ í $\tau \omega$ 'engender'.

It may be useful to have a look at the place of this formation in the original verbal system. Following a line of thought developed by Pedersen (1921: 25f.) and Kuiper (1934: 212), I reconstruct a hysterodynamic $s$-present, $3^{\text {rd }}$ sg. *tresti, $3^{\text {rd }}$ pl. *trsenti, beside a static $s$-subjunctive (Indo-Iranian aorist injunctive), $3^{\text {rd }} \mathrm{sg} . * t \bar{e} r s t, 3^{\text {rd }} \mathrm{pl} . *$ tersnt, the coexistence of which is perhaps best preserved in Tocharian (cf. already Kortlandt 1985: $117^{3}$ ), where we find B $t \ddot{a} s^{-}<* d h H_{l} e s-$ beside A $t \bar{a} s_{-}-<* d h H_{l} s^{-}$in the present and 
B tes-, A cas- $<* d h \bar{e} H_{1} s$ in the preterit of the verb $t \bar{a}-<* d h e H_{1^{-}}$'put'. If the reduplicated formations followed a similar pattern, we may reconstruct a hysterodynamic reduplicated present, Vedic $3^{\text {rd }}$ sg. vivakti 'speaks' $<*$ wiwek ${ }^{w} t i$, weak stem *wiwk ${ }^{w}$-, but with retracted stress in $3^{\text {rd }}$ pl. *wewk ${ }^{w} n t i$, cf. $3^{\text {rd }}$ sg. sísakti, $3^{\text {rd }}$ pl. sáścati 'accompany' < ${ }^{*}$ sisek $^{w} t i,{ }^{*}{ } e s k^{w} n t i$, beside a static reduplicated subjunctive (Indo-Iranian aorist injunctive), $3^{\text {rd }} \mathrm{sg}$. *wēw $k^{w} t, 3^{\text {rd }} \mathrm{pl}$. *wewk $k^{w} n t$, Vedic ávocat 'he spoke', subjunctive vócati beside vócăti. This reconstruction actually explains the long $*_{-}-\bar{e}$ in the reduplication syllable of original reduplicated aorists, as opposed to original presents and perfects, in Tocharian (cf. Kortlandt 1996: 173). The original accentuation of the hysterodynamic reduplicated present is preserved in Vedic $3^{\text {rd }} \mathrm{sg}$. juhóti, $1^{\text {st }} \mathrm{pl}$. juhumás, $3^{\text {rd }}$ pl. júhvati 'sacrifice'. For the reduplication syllable cf. also $3^{\text {rd }}$ sg. yuyóti 'separates', aorist injunc-

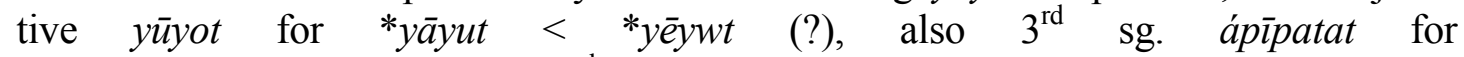
$*_{-}$pāp $(t)<*$ *ēpt beside ápaptat, $3^{\text {rd }}$ pl. ápaptan 'flew' for *-paptat $<*$ peptnt, and jáhāti 'leaves' beside jihite 'goes forth', further $2^{\text {nd }} \mathrm{sg}$. vavákși beside $3^{\text {rd }}$ sg. vivaști 'desires', imperative rirīhi beside subjunctive rárate 'give', also jígāti 'goes', jágat 'going, world',

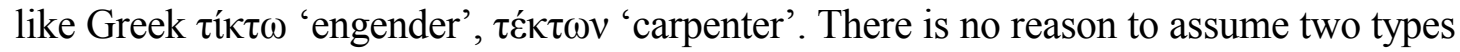
of reduplicated present which as a result of partial adaptation under mutual influence gave rise to four different combinations of accent and ablaut in Vedic (thus e.g. Harðarson 1993: $30^{14}$ ) because this assumption does not explain the coexistence of the two types of reduplication within a single paradigm. The rise of the static reduplicated present may have been provoked by the raising of pretonic $-e$ - to $-i$ - in the reduplication syllable (cf. Kortlandt 1987: 222).

If the historical background of the reduplicated formation proposed here is correct, we should expect full grade reduplication and zero grade root vocalism throughout the paradigm of the Vedic intensive. It follows that full grade root vocalism in the paradigm of the intensive is always the result of analogy after the hysterodynamic flexion types. Thus, I think that $1^{\text {st }} \mathrm{sg}$. dediśam 'point out' is the regular injunctive form and that e.g. $2^{\text {nd }} \mathrm{sg}$. dardar 'split', $3^{\text {rd }} \mathrm{sg}$. adardhar 'held' are analogical for *dardur, *adardhrt, which were anomalous forms. On the other hand, $3^{\text {rd }} \mathrm{pl}$. forms in $-a t<*-n t$ could easily give rise to a thematic injunctive paradigm with $3^{\text {rd }} \mathrm{sg}$. - at and $3^{\text {rd }} \mathrm{pl}$. -an, e.g. davidyutat or -an 'flashed' (cf. Thieme 1929: 12f., Hoffmann 1967a: 200f., Schaefer 1994: 41). Jamison asks the question "why the intensive was not thematized throughout: it is the restriction, the relative rarity of these thematic forms that is curious, not their existence" (1983: 48). The answer is precisely that the subjunctive had zero grade root vocalism in the intensive so that the thematic paradigm existed already with a different function. Since the intensive was the only athematic present without full grade vocalism in the predesinential syllable of the active singular forms, the analogical introduction of a full grade root vowel is only to be expected, e.g. dávidyot for *-dyut beside davidyutat or -an. Interestingly, the two instances which Jamison adduces as clear examples of thematized injunctives, as opposed to subjunctives, are precisely the $3^{\text {rd }} \mathrm{pl}$. forms carkiran 'commemorate' and pāpatan 'fly' (1983: 47), where -an may have replaced -at $<*_{-}$t (cf. also Schaefer 1994: 41f. and Lubotsky 1997: 561), like -anta replacing -ata in the middle. This replacement must have been earlier than the general substitution of -ur for $*_{-a t}<*_{-}$t in Vedic (cf. Kortlandt 1981: $129^{2}$ ).

As I have argued elsewhere (1987), the $3^{\text {rd }}$ pl. form occupies a special position in the paradigm. This is clear not only from the alternating vowel in the reduplication syllable of $3^{\text {rd }} \mathrm{sg}$. sísakti, $3^{\text {rd }}$ pl. sáścati 'accompany' and jígāti 'goes', jágat 'going, world', but also from the alternating vocalism in the active and middle root aorist and in the paradigm of the optative. As Meillet noticed a long time ago (1920: 202-205), the $3^{\text {rd }} \mathrm{pl}$. 
middle indicative forms ákrata 'made', arrata 'went' correspond to the injunctive forms kranta, ranta. The archaic character of this distribution is supported by the isolated $3^{\text {rd }}$ pl. injunctive forms naśan and naśanta 'attain', which correspond to indicative äkșisur (for āsur replacing *āśat) and āśata. Hoffmann's conjecture that the initial $n$ - of the injunctive is of secondary origin (1957: 124f.) does not explain why it is limited to the $3^{\text {rd }}$ pl. forms, cf. $3^{\text {rd }}$ sg. middle asta. In the active root aorist we find $3^{\text {rd }} \mathrm{pl}$. ásthur 'stood', ávran 'covered' beside the corresponding injunctive forms sthúr, vrán, which suggest an original alternation between double zero grade in the indicative and a full grade ending in the injunctive. This distribution must be old because the double zero grade is supported by comparative evidence from Greek, where $3^{\text {rd }}$ pl. $\varepsilon \Leftrightarrow \varepsilon \alpha v$ 'put' replaces earlier $*{ }^{*} \theta \alpha v$, with loss of the laryngeal and vocalization of the nasal (cf. Kortlandt 1988: 67), and from Germanic, where original *dunp is reflected in the Old English preterit sg. dyde, pl. dydon 'did' (cf. Kortlandt 1989: 102). In the optative, the alternation between a full grade suffix in the singular and double zero grade in the suffix and the ending in the $3^{\text {rd }} \mathrm{pl}$. form is best preserved in the Old Church Slavic je-presents xošte- 'want' and dovilje- 'satisfy', which have *-iHnt in $3^{\text {rd }}$ pl. xotętŭ and dovı̆lętŭ, corresponding to Latin velint, Gothic wileina (cf. Kortlandt 1987: 221). As in the case of the reduplicated presents, there is no reason to assume different flexion types in the optative, an assumption which does not explain the coexistence of the two types within a single paradigm. Instead we must reconstruct an original alternation between suffixal stress in the active singular, desinential stress in the active $1^{\text {st }}$ and $2^{\text {nd }}$ pl. forms and in the middle, and root stress in the active and middle $3^{\text {rd }} \mathrm{pl}$. forms. This reconstruction actually offers an explanation for the Vedic isolated $1^{\text {st }} \mathrm{pl}$. form naśimmahi $(3 \mathrm{x})$ beside aśìmahi $(5 \mathrm{x})$ 'attain', which suggests that this paradigm also contained a form with full grade in the root. Since the initial $n$ - is lacking elsewhere in the middle optative and indicative paradigms, it was probably taken from the unattested $3^{\text {rd }} \mathrm{pl}$. middle optative form.

The reconstruction of a triple accent and ablaut alternation advocated here also accounts for the root aorist optative type exemplified by $1^{\text {st }} \mathrm{sg}$. Vedic dheyām, Greek $\theta$ cínv 'put' (cf. Harðarson 1993: 126-142 for a survey of the scholarly literature). In his elaborate treatment, Insler connects the type dheyām with the type gaméyam, the two being in complementary distribution (1975: 15). His explanation falters on two points. First, it requires the previous existence of both *dheyam and *dhay $\bar{a} m$, of which the attested form represents a blending. It is highly improbable that neither of the earlier forms would have survived because both were supported by other paradigms, while the alleged blending created a new type. Second, the motivation for the spread of the new vocalism to the third person forms is very weak. The long chain of analogic changes which Insler's theory requires is too complicated to be credible. Thus, I think that the paradigm of dheyām was based on the $3^{\text {rd }} \mathrm{pl}$. form *dhaHiHat, which had full grade in the root and double zero grade in the suffix and the ending, because the zero grade of the root was reduced to $d h$ - before the optative suffix $-y \bar{a}-,-\bar{l}$ - in the other persons. Similarly, Greek introduced the stem vowel from $3^{\text {rd }}$ pl. *thein into the other persons, where the zero grade of the root had been reduced to th- before $-i \bar{e}-,-\bar{l}$ - (cf. Kortlandt 1992: 238). The disyllabic character of *theīn is still preserved in $\tau \imath \theta \varepsilon \tau \varepsilon v<*$ titheì-en 'they may put',

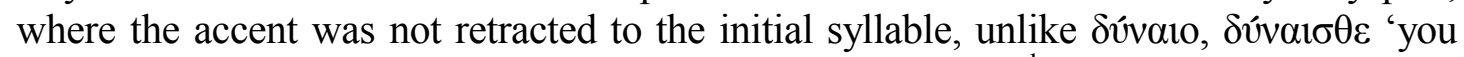
may be able', which replace earlier *dunisso, *dunisthe. The $3^{\text {rd }}$ pl. ending of the sigmatic aorist optative $*_{-} \sin <*_{-} \sin t$, which had become homophonous with $1^{\text {st }} \mathrm{sg} . *_{-} \sin <*_{-s i m}$, was replaced by *-sein on the analogy of *thein, the ending of which was also found in the passive aorist and in the paradigm of i $\mu \mu \mathrm{r}$ 'let go'. This is the origin of the so-called 
Aeolic optative. ${ }^{1}$ The correctness of these reconstructions is corroborated by the Old High German preterit subjunctive (Indo-European optative) of weak verbs. The difference between Alemannic nāmi 'took' and suohtī 'sought' (Notker nâme versus suohtî), which cannot be explained as a secondary development, shows that the two paradigms represent different formations. While nāmi can be compared with wili 'wants' (Notker wile) and derived from $*_{-}-\bar{t}$, the weak ending $-t \bar{\imath}$ must be compared with Vedic $1^{\text {st }} \mathrm{sg}$. dheyām, $3^{\text {rd }} \mathrm{pl}$. dheyur, Greek $\theta \varepsilon i ́ \eta v, \theta \varepsilon \tau \varepsilon v$, and derived from * dheìt (cf. Kortlandt 1989: 105). It provides conclusive evidence for the compound origin of the Germanic weak preterit.

The peculiar accentuation of the $3^{\text {rd }} \mathrm{pl}$. forms such as Vedic tákșati 'fashion', sáścati 'accompany', júhvati 'sacrifice', *jágati 'go', ákrata 'made', àrata 'went', naśan, naśanta, āśata, ākșișur 'attain(ed)', ásthur 'stood', ávran 'covered', dheyur 'put' points to a different origin from the other forms of the verbal paradigm. In fact, the accentual alternation in $1^{\text {st }} \mathrm{sg}$. juhómi, $3^{\text {rd }} \mathrm{sg}$. juhóti, $1^{\text {st }}$ pl. juhumás, $3^{\text {rd }}$ pl. júhvati 'sacrifice' suggests that these forms have three distinct origins: the singular looks like a regular verbal paradigm, with suffixed endings which may go back to clitics, while the $1^{\text {st }} \mathrm{pl}$. form resembles a derivative, perhaps a compound, and the $3^{\text {rd }} \mathrm{pl}$. form has the appearance of a participle. As I pointed out earlier (1987: 222), I think that the form in -nti represents the original nom.pl. form of the participle, with the Indo-Uralic plural ending $-i$ which is also found in the Proto-Indo-European pronominal inflection, e.g. * toi 'they, these', gen. *toisom, etc. Since Beekes's discussion of Latin iens, eunt- 'going' (1985: 67-71), we have to start from a reconstructed paradigm with nom.sg. ${ }^{*} H_{1}$ eints, acc.sg. ${ }^{*} H_{l} i e n t m$, gen.sg. ${ }^{*} H_{1}$ intos, in which Vedic $3^{\text {rd }}$ pl. yánti $<* H_{1}$ ienti may have been the original nom.pl. form of the participle. If the present indicative *trsenti and the aorist injunctive *tersnt originally belonged to the same paradigm, the latter form looks like the original neuter of the participle. This is indeed the expected form if the agent of a transitive verb in the aorist was in the ergative case (cf. Kortlandt 1983). Thus, I tentatively reconstruct present indicative *toi trsenti beside aorist injunctive *tois tersnt, where *tois is the original ergative from which the genitive *tois-om and the instrumental *to-ois were derived. ${ }^{2}$ It appears that the participial form was cliticized after the augment in Vedic ásthur 'stood' for *ásthat $<* H_{1} e-s t H_{2} n t$, also ákrata 'made' $<*^{*} H_{1} e-k r n t$-, and after the reduplication, e.g. neuter dádhat 'putting' $<*$ dhedhH $H_{1} n t, 3^{\text {rd }}$ pl. dádhati $<* d h e d h H_{1} n t i$. In this view, forms like naśan, naśanta 'attain', ávran 'covered' adopted the full grade ending on the analogy of the primary (i.e. nom.pl.) form in *-enti, whereas the static paradigm is ultimately based on the secondary (i.e. neuter) form with zero grade * ${ }_{-n t}$ exemplified in *tersnt and *dhedhH $H_{1} n t$. The model for the creation of the full grade secondary endings *-ent, ${ }^{*}$-ento beside primary ${ }^{*}$-enti was of course provided by $3{ }^{\text {rd }} \mathrm{sg} . *^{*} t$, *-to beside *-ti, while the zero grade primary ending of dádhati 'they put' may have been the original nom.pl. ending of the reduplicated participle.

The remaining question is why the lengthened grade was eliminated from the Indo-

\footnotetext{
${ }^{1} \mathrm{Cf}$. ibidem. The ending *-sein was subsequently replaced by *-seiyan on the analogy of the thematic ending *-oiyan. This replacement accounts for the retraction of the accent in $\lambda \dot{v} \sigma \varepsilon 1 \alpha v$ 'they may loosen' in accordance with the limitation law. In the original paradigm with mobile stress, the 3rd pl. ending *-in was replaced by *-iyen on the basis of the indicative paradigm, e.g. $\tau 1 \theta \varepsilon \tilde{\varepsilon} \varepsilon v * *^{*}$ titheïyen, also Delphi $\pi \varepsilon \rho u \varepsilon ı v \nu<$


*weideïyen 'he, they may know' represent * widieH $_{l} t$ (Vedic vidyất), *weidiH $H_{l} n t$ (with original full grade in the root) plus *-ei- from *thein and the 3rd pl. ending *-ent.

${ }^{2}$ A typological parallel is offered by the dialectal Russian (plu)perfect, e.g. v jix košali bal'šýje nabito (býli) sénom 'they had/ve filled the big bags with hay' (cf. Honselaar 1998: 303), literally: at them [gen.pl.] bag [nom.pl.] big [nom.pl.] filled [neuter past participle] (were [pl.]) hay [inst.sg.].
} 
Iranian root aorist, e.g. Vedic $3^{\text {rd }}$ sg. ágan 'went' $<*_{-} g^{w} e m t$, cf. Latin vēnit, Gothic $q \bar{e} m$-, Toch. B śem 'came' $<{ }^{*} g^{w} \bar{e} m-$. As in the case of the $s$-present and the $s$-aorist, I think that we have to start from a reduplicated present indicative, $3^{\text {rd }} \mathrm{sg}$. *wiwek ${ }^{w} t i, 3^{\text {rd }}$ pl. *wewk $k^{w} n t$, beside a reduplicated aorist injunctive, $3^{\text {rd }} \mathrm{sg} . *^{*} w \bar{e} w k^{w} t, 3^{\text {rd }}$ pl. *wewk $k^{w}$, cf. Vedic vivakti 'speaks', ávocat 'spoke'. The meaning of this formation must have been iterative or intensive (cf. Bybee et al. 1994: 166-174 on the semantic development of reduplicated formations). When lengthened grade superseded reduplication in the active singular of the static present, first in $T e K$-roots such as tấști 'fashions', dâsț̣i 'makes offering', then analogically in mấrști 'wipes', stáuti 'praises', the long vowel became characteristic of this type of derived present and thereby anomalous in the paradigm of the root aorist, where it was limited to the $2^{\text {nd }}$ and $3^{\text {rd }}$ sg. injunctive forms and could easily be eliminated, cf. $3^{\text {rd }} \mathrm{sg}$. imperfect akrāmat beside aorist akramit 'strode'. The original lengthened grade may have been preserved in $2^{\text {nd }}$ and $3^{\text {rd }} \mathrm{sg}$. akrān 'cried', asyān 'moved', arraik 'left', acait 'perceived', aśvait 'brightened', adyaut 'shone', which are isolated in the paradigm of the root aorist and could be reanalyzed as sigmatic aorist forms. The hypothesis that these forms are independent analogical creations (Narten 1964: 18) does not explain their isolated character in the oldest texts. I therefore think that they may be relics from the stage when lengthened grade had not yet adopted the function of reduplication in the static present, which provoked its elimination from the root aorist.

\section{References}

Beekes, Robert S.P. 1985. The origins of the Indo-European nominal inflection (Innsbruck: Institut für Sprachwissenschaft).

Bybee, Joan, Revere Perkins \& William Pagliuca. 1994. The evolution of grammar: Tense, aspect, and modality in the languages of the world (Chicago: University Press).

Harðarson, Jón Axel. 1993. Studien zum urindogermanischen Wurzelaorist (Innsbruck: Institut für Sprachwissenschaft).

Hoffmann, Karl. 1957. Zur vedischen Verbalflexion. Münchener Studien zur Sprachwissenschaft $2^{2}, 121-137$.

Hoffmann, Karl. 1967a. Der Injunktiv im Veda (Heidelberg: Carl Winter).

Hoffmann, Karl. 1967b. Der vedische Prekativtyp yeșam, jeșma. Münchener Studien zur Sprachwissenschaft 20, 25-37.

Honselaar, Zep. 1998. The dialect of Ostrovcy in the Pskov oblast. Dutch Contributions to the Twelfth International Congress of Slavists (Amsterdam: Rodopi) $=$ Studies in Slavic and General Linguistics 24, 283-307.

Insler, Stanley. 1975. The Vedic type dheyām. Die Sprache 21, 1-22.

Jamison, Stephanie W. 1983. Two problems in the inflection of the Vedic intensive. Münchener Studien zur Sprachwissenschaft 42, 41-73.

Kortlandt, Frederik. 1981. 1st sg. middle *-H2. Indogermanische Forschungen 86, 123-136.

Kortlandt, Frederik. 1983. Proto-Indo-European verbal syntax. Journal of IndoEuropean Studies 11, 307-324.

Kortlandt, Frederik. 1985. Long vowels in Balto-Slavic. Baltistica 21, 112-124.

Kortlandt, Frederik. 1987. Archaic ablaut patterns in the Vedic verb. Festschrift for Henry Hoenigswald (Tübingen: Gunter Narr), 219-223. 
Kortlandt, Frederik. 1988. The Greek 3rd pl. endings. Münchener Studien zur Sprachwissenschaft 49, 63-69.

Kortlandt, Frederik. 1989. The Germanic weak preterit. Amsterdamer Beiträge zur älteren Germanistik 28, 101-109.

Kortlandt, Frederik. 1992. The Aeolic optative. Rekonstruktion und relative Chronologie: Akten der VIII. Fachtagung der Indogermanischen Gesellschaft [Leiden, 1987] (Innsbruck: Institut für Sprachwissenschaft, 1992), 235-239.

Kortlandt, Frederik. 1996. The Tocharian imperfect. Historische Sprachforschung 109, 169-174.

Kuiper, Franciscus B.J. 1934. Zur Geschichte der indoiranischen s-Präsentia. Acta Orientalia 12, 190-306.

Lubotsky, Alexander. 1994. RV. ávidhat. Früh-, Mittel-, Spätindogermanisch (Wiesbaden: Ludwig Reichert), 201-206.

Lubotsky, Alexander. 1997. Remarks on the Vedic intensive [Review of Schaefer 1994]. Journal of the American Oriental Society 117, 558-564.

Meillet, Antoine. 1920. Sur le rhytme quantitatif de la langue védique. Mémoires de la Société de Linguistique de Paris 21, 193-207.

Narten, Johanna. 1964. Die sigmatischen Aoriste im Veda (Wiesbaden: Otto Harrassowitz).

Pedersen, Holger. 1921. Les formes sigmatiques du verbe latin et le problème du futur indo-européen (København: Kgl. Danske Videnskabernes Selskab).

Ruijgh, Cornelis J. 1998. Review of Harðarson 1993. Mnemosyne 51, 216-227.

Schaefer, Christiane. 1994. Das Intensivum im Vedischen (Göttingen: Vandenhoeck \& Ruprecht).

Thieme, Paul. 1929. Das Plusquamperfektum im Veda (Göttingen: Vandenhoeck \& Ruprecht).

Wackernagel, Jakob. 1896. Altindische Grammatik I: Lautlehre (Göttingen: Vandenhoeck \& Ruprecht). 